\title{
THE DISTRIBUTION AND DIVERSITY OF SPIDERS (ARACHNIDA: ARANAE) IN SAHENDARUMAN MOUNTAIN, SANGIHE ISLANDS, NORTH SULAWESI, INDONESIA
}

\author{
KONERI, R. ${ }^{{ }^{*}}-$ NANGOY, M.-J. ${ }^{2}$ \\ ${ }^{I}$ Department of Biology, Sam Ratulangi University, Campus Sam Ratulangi University Street, \\ Bahu, Manado, North Sulawesi 95115, Indonesia \\ (phone: +62-813-4027-5276) \\ ${ }^{2}$ Department of Animal Production, Sam Ratulangi University, Campus Sam Ratulangi \\ University Street, Bahu, Manado, North Sulawesi 95115, Indonesia \\ (phone: +62-812-4239-9445) \\ *Corresponding author \\ e-mail: ronicaniago@unsrat.ac.id \\ (Received $8^{\text {th }}$ Jan 2017; accepted $16^{\text {th }}$ Mar 2017)
}

\begin{abstract}
Spiders play an important role in the ecosystem. They are the controller agent of the biodiversity and therefore they should be preserved. This study aims to analyze the distribution and diversity of spider (Arachnida: Araneae) in Sahendaruman Mountain, the Islands of Sangihe, North Sulawesi, Indonesia. The sample is taken from three types of habitat including the secondary forest, shrub and plantation area. The sample is obtained using a pitfall trap and a sweep net. The data analysis includes the richness, abundance, diversity and evenness of species between the habitats. The results show that there are 15 families, 117 morphospecies and 812 individual spiders identified. The abundance and the number of family species that are mostly found is Salticidae, followed by Thomisidae. The distribution of the spiders shows that 13 families are spread out in all types of the habitats and two families only inhabit one type of the habitats. The highest level of richness, abundance, diversity and evenness of the spider species is found in the secondary forest, while the lowest level are found in the shrub. The results reveal that the secondary forest has the highest diversity of spiders compared to the other habitat.
\end{abstract}

Keywords: pitfall traps, sweep nets, Salticidae, secondary forest, species richness

\section{Introduction}

The protected forest of Sahendaruman Mountain is one of the conservation parks located in the Sangihe Island, North Sulawesi, Indonesia. Sangihe is one of the big islands in the group of Sangihe Islands and Talaud extending from north end of Sulawesi to South end of Mindanau island in the Philippines. The area is established as protected forest with the width of 3.549 ha as stated in the letter from Ministry of Forestry and Plantation No.452/ks-/1999 on June 1999. Sahendaruman Mountain is located at $03^{0} 30.99 \mathrm{~S}$ and $125^{0} 31.25 \mathrm{E}$ and is 1.031 meter from the sea level. The area of the mountain is one of the tropical forest and the center of the biodiversity of Sangihe Island in which diversity of endemic flora and fauna whose living depends on the original forest left (Kainde, 2011).

Spider is one of the fauna in the area of protected forest of Sahendaruman Mountain. A spider has two parts of the body including cephalothorax and abdomen (Oyewole and Oyelade, 2014). This animal belongs to the filum of Arthropoda, class of Arachnida, ordo Araneae and is also the biggest group with the highest diversity (Puja, 2014; Enriquez and Nuñeza, 2014). To date, there are around 45.829 spider's species have been described, which are classified into 114 race and 3977 genera (American Museum 
of Natural History, 2016). Approximately, the number of spider's species in the world can reach up to 170, 000 species (Mineo and Claro, 2010).

Spider is classified as generalist predator and has a great influence toward the structure of the community, especially the food chain and food web. Spiders play important role as the predator, especially the predator of insects and therefore they contribute to control the insect population (Borror et al., 1996; Kostanjšek et al., 2015). Spiders can also be the biodiversity controller agent for various insect pests due to their polyphagous characteristic. Based on the roles mentioned, it shows that spider is important in the food chain. Spiders also play important role in the agriculture, plantation and housing to protect from the pest insects (Brunet, 2000). Furthermore, spiders can also be the bio indicator for the change of the environment (Kapoor, 2006).

Tropical forest has a huge diversity of spider species (Suana, 2004). Spider likes the habitat that is protected from the heat, easy for them to attach their web, safe from the nest or web destruction as well as the place that can maximize their time in searching for the prey (Morse, 1984; Pollard et al., 1995). The diversity of spiders in the ecosystem is influenced by several factors (Larrivee and Buddle, 2010). The change of the ecosystem from a tropical forest to a plantation area and a settlement will affect the diversity of spiders living in the ecosystem. The decrease of the vegetation diversity in the tropical forest will lead to the decrease of the diversity of spiders (Samu et al., 1996; Reichert and Lockley, 1984). On the other hand, the structure and complexity of an ecosystem will also increase the abundance of spiders (Reichert and Lockley, 1984; Chew, 1961).

The forest destruction and the changing function of the land in Sahendaruman Mountain could have an impact on the flora and fauna living in the area including spiders. Therefore, the current distribution and diversity of spiders needs to be evaluated. This study aims to analyze the distribution and diversity of spider in Sahendaruman Mountain, the Islands of Sangihe, North Sulawesi, Indonesia.

\section{Materials and Methods}

\section{Study area and land-use types}

The sampling is conducted in four months from March to June 2016 in Sahendaruman Mountain, the Islands of Sangihe, North Sulawesi, Indonesia (Figure 1). The secondary forest is the forest that is growing and develop naturally after the destruction of the primer forest. The forest destruction in this location was occurred 4050 years ago. Several trees are growing in this area including Alstonia macrophylla (Apocynaceae), Ficus sp (Moraceae), Macaranga sp (Euphorbiaceae) and Garcinia sp (Clusiaceae). The habitat is located at $522-560 \mathrm{~m}$ above the sea level. The coordinates of sampling in each transect are $03^{\circ} 28^{\prime} 45.19^{\prime \prime} \mathrm{S} / 125^{\circ} 31^{\prime} 03.76^{\prime \prime} \mathrm{E}$ (plot 1); 03 $28^{\prime} 48.84^{\prime \prime S} /$ $125^{\circ} 31^{\prime} 03.83^{\prime \prime E}$ (plot 2); and $03^{\circ} 28^{\prime} 55.98^{\prime \prime} \mathrm{S} / 125^{\circ} 31^{\prime} 03.68^{\prime \prime E}$ (plot 3). The temperature in the habitat is around $27^{\circ} \mathrm{C}-29^{\circ} \mathrm{C}$, the air humidity is approximately $71 \%-78 \%$, and the depth of leaf litter is $10-15 \mathrm{~cm}$.

The plantation area is the habitat outside the protected forest of Sahendaruman Mountain. This habitat is managed by the society and planted with cloves (Syzygium aromaticum). The sampling is located at $410-427 \mathrm{~m}$ above the sea level. The coordinates of each plot are $03^{\circ} 28^{\prime} 26.98^{\prime \prime} \mathrm{S} / 125^{\circ} 30^{\prime} 57.63^{\prime \prime} \mathrm{E}$ (plot 1); 03 ${ }^{\circ} 28^{\prime} 28.42^{\prime \prime} \mathrm{S} /$ $125^{\circ} 30^{\prime} 59.22^{\prime \prime E}$ (plot 2); and 03 $28^{\prime} 31.46^{\prime \prime} \mathrm{S} / 125^{\circ} 31^{\prime} 01.80^{\prime \prime} \mathrm{E}$ (plot 3). The temperature in the habitat is around $28^{\circ} \mathrm{C}-30.5^{\circ} \mathrm{C}$, the air humidity is approximately $73 \%-75 \%$ and the depth of leaf litter is $8-11 \mathrm{~cm}$. 


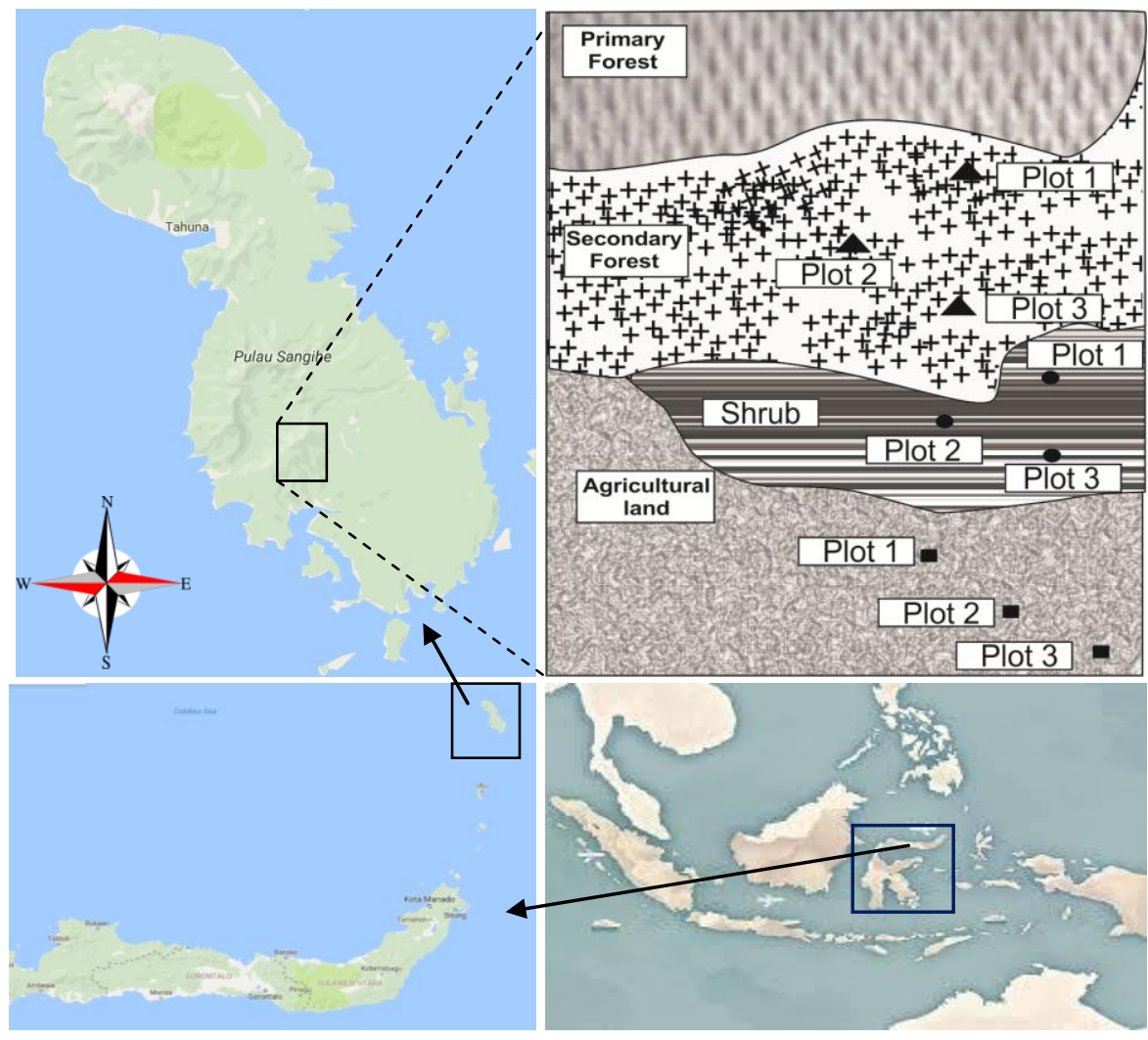

Figure 1. Map of the study area

The shrub is the neglected land, used to be forest and plantation, in which shrubs grow and dominated by Imperata cylidrica dan bamboo (Bambusa sp). The sampling is located at $481-503 \mathrm{~m}$ above the sea level. The coordinates of each plot are $03^{\circ} 28^{\prime} 37.98^{\prime \prime S} / 125^{\circ} 31^{\prime} 03.83^{\prime \prime E}$ (plot 1); 03² $8^{\prime} 40.65^{\prime \prime S} / 125^{\circ} 31^{\prime} 03.92^{\prime \prime E ~(p l o t ~ 2) ; ~ a n d ~}$ $03^{\circ} 28^{\prime} 42.39^{\prime \prime} \mathrm{S} / 125^{\circ} 31^{\prime} 04.14 " \mathrm{E}$ (plot 3 ). The temperature in the habitat is around $29.9^{\circ} \mathrm{C}-32.0^{\circ} \mathrm{C}$, the air humidity is approximately $50 \%-60 \%$, and the depth of leaf litter is $1-4 \mathrm{~cm}$.

\section{Sampling}

The sampling is conducted in three types of habitat namely, secondary forest, shrub and plantation area (Figure 2). Three plots of $50 \mathrm{~cm} \times 50 \mathrm{~cm}$ are created in each type of habitat with the distance between each plot is $500 \mathrm{~m}$. Four transects with the length of $50 \mathrm{~m}$ are created in each plot and the distance between the transects is $15 \mathrm{~m}$. The sample is obtained using a pitfall trap and a sweep net. The pitfall trap is to collect spiders that move on the surface of the ground and the sweep net is to get the spiders that inhabit the vegetation (Vincent and Hadrien, 2013). The pitfall trap used in this study is made of plastic cylinder planted in the ground (the measurement are volume $20 \mathrm{~m}$, diameter 5.3 $\mathrm{cm}$ and height is $9.8 \mathrm{~cm}$ ). The plastic cylinder is filled half full with the solution consisting one litre of water, three spoons of detergent and three spoons of salt. The surface of the cylinder is at the same level of the ground. The plastic cylinder is covered by shade to avoid the rainfall. The spiders that pass by the trap is expected to be trapped and died in the cylinder. There are five traps in one transect with the distance between 
the traps is $50 \mathrm{~m}$. There are 20 traps in each habitat. The trap should be placed for 48 hours (Suana, 2004). The sample of trapped spiders is then kept in eppendorf tube filled with 95 per cent of alcohol.

The collection of spiders from the sweep net is obtained by swinging the net hundred times in each transect from 09.00 am to $15: 00 \mathrm{pm}$, Indonesian east time. The measurement of the cone net is $60 \mathrm{~cm}$ depth, $300-380 \mathrm{~cm}$ diameter, and the length of the net stick depending on the height of the plants.

The sampling using the pitfall trap and sweep net is conducted for four months. The spiders collected are kept in the Eppendorf tube filled with 95 per cent of alcohol. The sample taken from the pitfall trap and sweep net are then identified and counted individually. The process of identification is based on the external morphology provided in the book written by Borror et al. (1996), 'Spider and their kin' (Levi and Levi, 1990), and the 'Riceland spider of South and Southeast Asia' written by Barrion and Litsinger (1995).
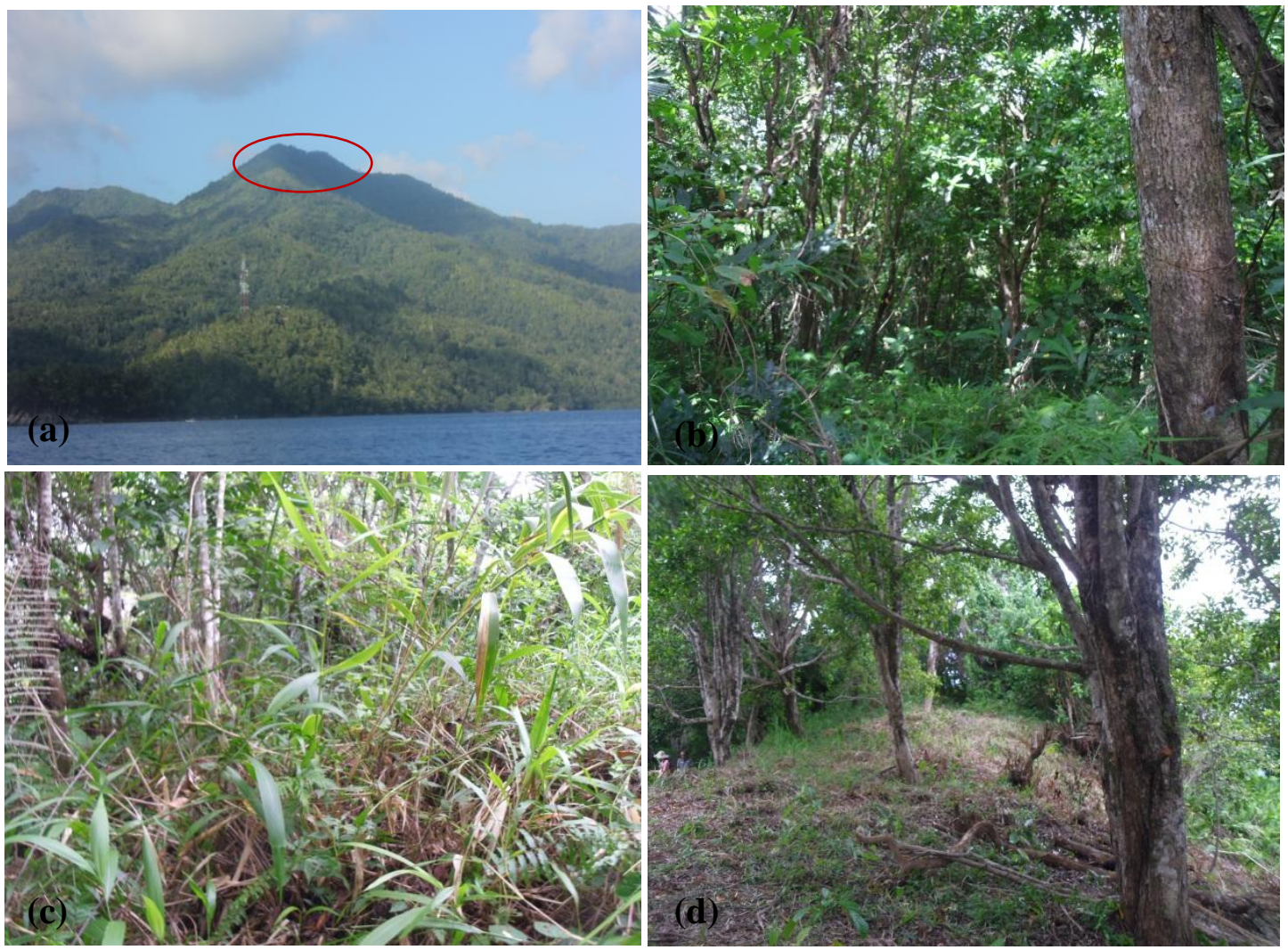

Figure 2. Photographs of study sites (a) Sangihe Island and Sahendaruman Mountain ( $\bigcirc$ ), (b) secondary forest, (c) shrub, (d) plantation area

\section{Data analyses}

The data analysis discussed in this study includes the abundance of the species (n), the richness of the species (s), the diversity of the species $(\mathrm{H})$ and the evenness of the species (E). The abundance of the species is the number of individual species found in each plot of sampling while the richness of the species is based on the number of species appear in each location of the study. The diversity of the species is determined 
by the diversity index $(\mathrm{H})$ of Shannon and Weaner in Magurran (1988), using the following formula:

$$
\text { Species diversity index }\left(\mathrm{H}^{\prime}\right)=-\sum_{i=l}^{s}\left(\mathrm{P}_{\mathrm{i}}\right)\left(\ln \mathrm{P}_{\mathrm{i}}\right)
$$

Where: $\mathrm{P}_{\mathrm{i}}=$ The proportion of each species $; \ln =$ Natural logarithm (natural number). The evenness of the species is determined by the evenness index of Shannon (E) (Magurran, 2004), using the following formula: $E=H / \ln (S) ; \quad E=$ evenness; $S=$ The number of species.

The analysis is carried out using Statistica 6. One way ANOVA and Tukey's test with 95 per cent of confidence interval are employed to examine the differences of the richness of the species, the abundance of the species, the diversity value of the species as well as the evenness of the species in each type of habitat (StatSoft, 2001; Ohsawa, 2005).

\section{Results}

The results show that there are 15 families, 117 morphospecies and 812 individual spiders found. The abundance and the number of family species that are mostly found is Salticidae $(35.10 \%)$, followed by Thomisidae $(16.26 \%)$. The Salticidae is also the family that has the biggest number of species identified (31 morphospecies), followed by the family of Thomisidae (22 morphospecies) as shown in Table 1 and Figure 3.

Table 1. Number of family, genera, morphospecies and individuals found in three types of habitat at Mount Sahendaruman, North Sulawesi

\begin{tabular}{|c|c|c|c|c|c|c|c|c|c|}
\hline \multirow{3}{*}{ No } & \multirow{3}{*}{ Famili } & \multirow{3}{*}{ Guild } & \multirow{3}{*}{$\frac{\sum}{\text { Genera }}$} & \multirow{3}{*}{$\begin{array}{c}\sum \\
\text { Morpho } \\
\text { Species }\end{array}$} & \multicolumn{3}{|c|}{$\begin{array}{c}\text { Habitats/Number of } \\
\text { Individuals }\end{array}$} & \multirow{2}{*}{\multicolumn{2}{|c|}{ Total }} \\
\hline & & & & & \multirow{2}{*}{$\frac{\text { SF }}{\sum}$} & \multirow{2}{*}{$\frac{\mathbf{A L}}{\sum}$} & \multirow{2}{*}{$\begin{array}{c}\mathbf{S} \\
\sum\end{array}$} & & \\
\hline & & & & & & & & $\sum$ & $\%$ \\
\hline 1 & Araneidae & Orb weavers & 10.00 & 16.00 & 37.00 & 38.00 & 28.00 & 103.00 & 12.68 \\
\hline 2 & Clubionidae & Foliage runners & 1.00 & 5.00 & 7.00 & 10.00 & 2.00 & 19.00 & 2.34 \\
\hline 3 & Linyphiidae & Sheet webs & 3.00 & 3.00 & 4.00 & 1.00 & 2.00 & 7.00 & 0.86 \\
\hline 4 & Lycosidae & Ground runners & 3.00 & 4.00 & 9.00 & 6.00 & 9.00 & 24.00 & 2.96 \\
\hline 5 & Nephilidae & Orb weavers & 1.00 & 1.00 & 0.00 & 0.00 & 1.00 & 1.00 & 0.12 \\
\hline 6 & Oonopidae & Ground runners & 3.00 & 3.00 & 4.00 & 2.00 & 3.00 & 9.00 & 1.11 \\
\hline 7 & Oxyopidae & Stalkers & 1.00 & 5.00 & 8.00 & 5.00 & 5.00 & 18.00 & 2.22 \\
\hline 8 & Pholcidae & Space builders & 1.00 & 1.00 & 1.00 & 0.00 & 0.00 & 1.00 & 0.12 \\
\hline 9 & Salticidae & Stalkers & 22.00 & 31.00 & 82.00 & 93.00 & 110.00 & 285.00 & 35.10 \\
\hline 10 & Scytodidae & Ground runners & 1.00 & 1.00 & 8.00 & 25.00 & 21.00 & 54.00 & 6.65 \\
\hline 11 & Sparassidae & Foliage runners & 1.00 & 1.00 & 12.00 & 6.00 & 7.00 & 25.00 & 3.08 \\
\hline 12 & Tetragnathidae & Orb weavers & 2.00 & 5.00 & 3.00 & 4.00 & 1.00 & 8.00 & 0.99 \\
\hline 13 & Theridiidae & Space builders & 7.00 & 17.00 & 30.00 & 20.00 & 26.00 & 76.00 & 9.36 \\
\hline 14 & Thomisidae & Ambushers & 8.00 & 22.00 & 60.00 & 51.00 & 21.00 & 132.00 & 16.26 \\
\hline 15 & Zodariidae & Ground runners & 2.00 & 2.00 & 19.00 & 5.00 & 26.00 & 50.00 & 6.16 \\
\hline \multicolumn{3}{|c|}{ Grand Total } & 66.00 & 117.00 & 284.00 & 266.00 & 262.00 & 812.00 & 100.00 \\
\hline
\end{tabular}

SF: Secondary forest; AL: Plantation area; S; Shrub 


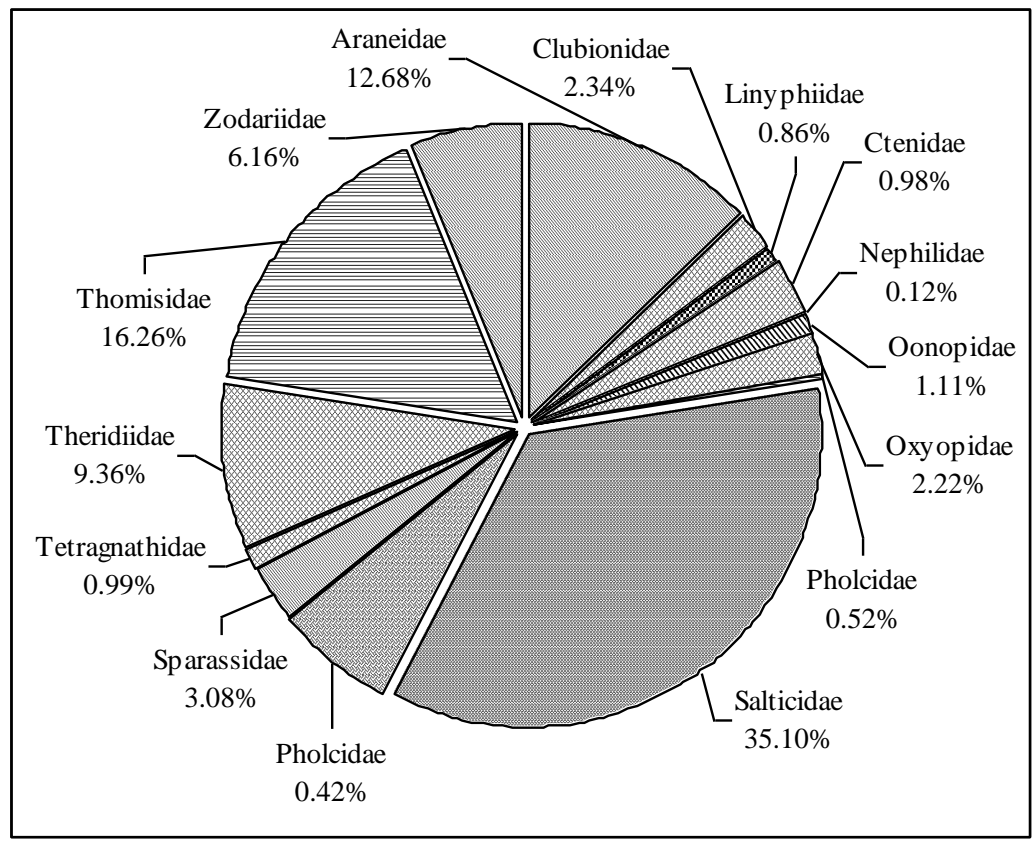

Figure 3. Abundance of family spiders found in three types of habitat at Mount Sahendaruman, North Sulawesi
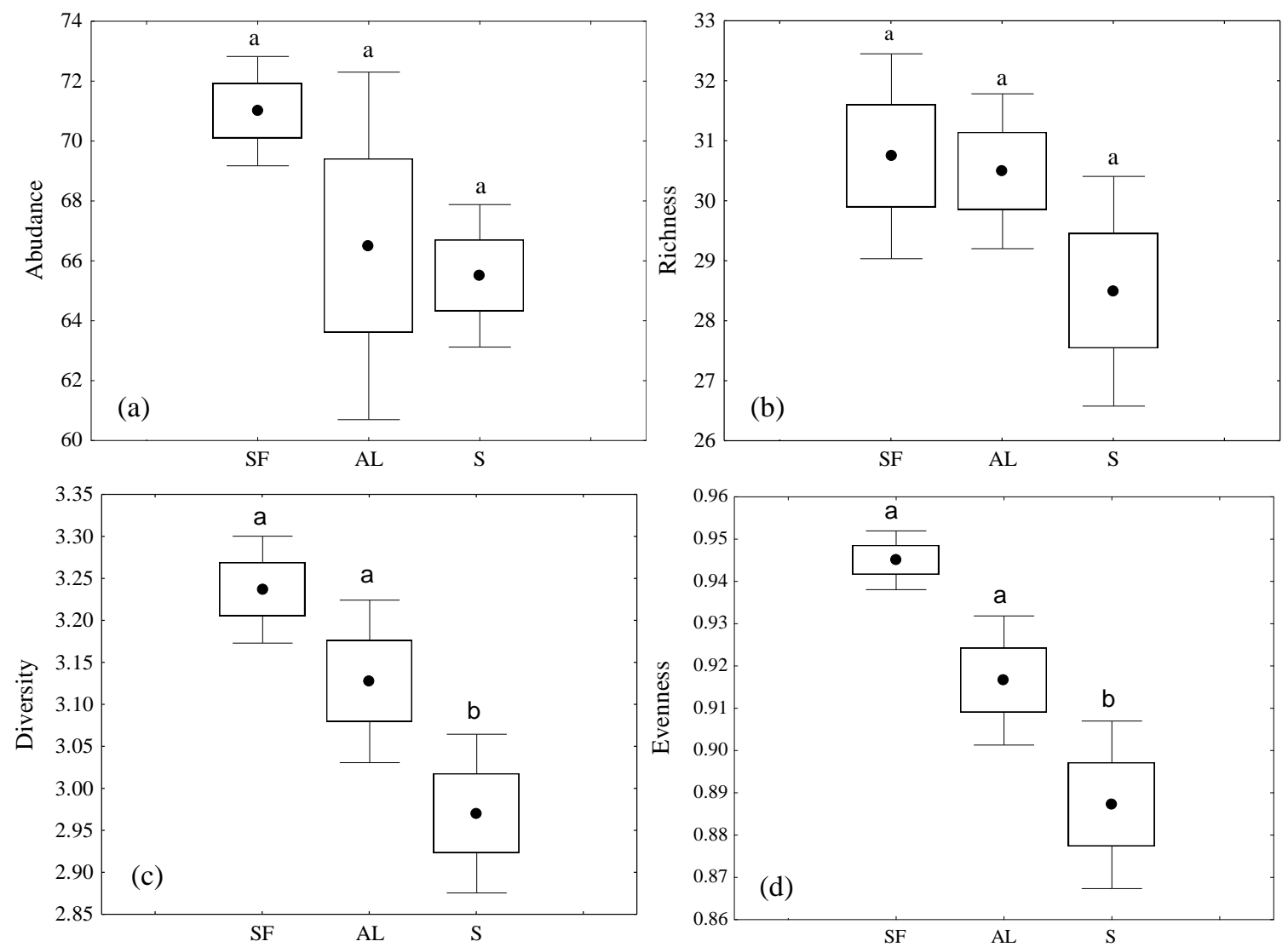

Figure 4. (a) Abundance, (b), richness, (c), diversity and (d) species evenness of spiders at three types of habitat in Mount Sahendaruman. (SF; Secondary forest; AL:

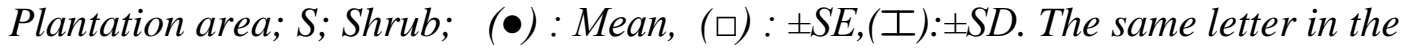
same plot did not differ significantly according to Tukey's test at $95 \%$ confidence level). 
The highest level of richness of the spider species is found in secondary forest (34.98 $\%$ ), while the lowest level is found in the shrub (32.27\%) as presented in Table 1. The results reveal that the secondary forest has the highest diversity of spiders compared to the other habitat. The distribution of the spiders shows that 13 families are spread out in all types of the habitats and two families only inhabit one type of the habitat. The family of Nephilidae is found only in the shrub and Pholcidae is found only in the secondary forest.

The highest level of abundance $(\mathrm{N}=53.00 \pm 4.08)$, richness $(\mathrm{S}=30.75 \pm 1,71)$, diversity $(\mathrm{H}=3.24 \pm 0.06)$ and evenness of species of the spiders $(\mathrm{E}=0.94 \pm 0.01)$ is found in the secondary forest and the lowest is found in the shrub. There is no dominant species in the secondary forest resulting in its evenness is being the highest among all habitat as shown in Fig. 3. The diversity and evenness of the species is tested statistically. The results show that there is no significant different of the abundance and richness of the species as presented in Figure 4. The diversity of the species of the spiders is the secondary forest is not significantly different from the plantation area. However, there is significant different of the abundance and richness of the species in the secondary forest and bushes $(\mathrm{F} 2,9=9.65 ; \mathrm{P}=0,005)$. Furthermore, the evenness of the species in the secondary forest is not significantly different from the plantation area but it is significantly different from the bushes $\left(\mathrm{F}_{2,9}=14.88 ; \mathrm{P}=0,001\right)$ (Figure 4).

\section{Discussion}

The number of the spider family identified in this study has only reached 8.07 per cent of the total family of spiders in Indonesia and New Guinea. The number of species of the spiders reported from Indonesia and New Guinea are 58 family, 505 genera, and 1954 species (Stenchly, 2011). The results of the study in the primary and disturbed tropical forests in Sabah, Malaysia on Borneo conducted by Floren (2005) reported there are 578 species in 29 families. The study of effects of forest fragmentation on canopy spider communities in Asian rain forests revealed that there are 33 families, 550 species and 5952 adult spiders found (Floren et al., 2011). The number of spiders (families, genera and species) recorded from Southeast Asia are 50 families, 249 genera, 660 species from Indonesia; 42 families, 181genera, 463 species from Malaysia; 43 families, 175 genera, 455 species from Myanmar; 39 families, 189 genera, 426 species from Philippines; 39 families, 186 genera, 308 species from Singapore; 35 families, 82 genera, 156 species from Thailand; and 30 families, 134 genera, 230 species from Vietnam (Song et al., 2002).

The number of family and species of spiders found can increase if the method used are not only pitfall traps and sweep net. Some previous studies using more than two methods in the sampling obtained more families and species of the spiders. Whitmore et al. (2002) recorded that there are 4832 individuals including 268 species from 38 families using four techniques in the sampling of the spiders, namely sweeping, beating, active searching and pitfall trapping. Cardoso et al. (2008) used six methods of the sampling of the spiders in their study and identified 29 families, 119 genera, and 204 species, the methods used include: (1) Aerial hand collection (2) Beat: branches of trees (3) Ground: hand collecting. (4) Sweep net, (5) Pitfall traps (6) Bark traps. Furthermore, the study related to diversity of spiders in Nanda Devi Biosphere Reserve conducted by Uniyal et al. (2011) found 244 species belong to 108 genera and 33 families using six technique of sampling including pitfall trapping, sweep netting, ground hand collecting, aerial hand collecting, vegetation beating, and litter sampling. 
The secondary forest has the highest level of abundance, richness, diversity and evenness of the species of the spiders compared to other habitat. Several factors influence the diversity of the spiders including the complexity of the structure of the vegetation, the depth of leaf litter and the human activities. The secondary forest is the primer forest that has been disturbed by the changing function of the forest to plantation area which is then neglected. To date, the secondary forest has succeeded in developing the more complex vegetation compared to the plantation area or the bushes. The complexity of vegetation in this habitat supports the life of spiders. McDonald (2007) reported that there is a relationship between the complex structure of the vegetation and the diversity of the species. the diversity generally increases when a greater variety of habitats are available (Hawksworth and Kalin-Arroyo, 1995).

Spiders is generally closely related to the characteristics of the plant community. The spiders which create the web is directly related to the architecture of the vegetation due to the pre requisite requirement to place the web. Several studies also demonstrated the effect of plant diversity on habitat structure and microclimatic characteristics (Bell et al., 2001; Schuldt et al., 2008). Tree species richness plays a prominent role in determining the canopy cover. Shading is important as it affects microclimatic conditions of the forest floor (Galle and Schweger, 2014). The abundance of orbweavers is influenced by the physical structure of the vegetation and the availability of web sites (Greenstone, 1984), the undisturbed bushes and sparse ground-layer vegetation in the secondary forest might be able to support a larger population of orbweaving spiders which require larger spaces for web construction (Chen and Tso, 2004).

The leaf litter in the forest floor also influence the existence of spiders. The secondary forest is one of the habitat that has higher depth of leaf litter compared to the other habitat. The leaves falling to the forest floor is the suitable habitat for the spiders which live in the leave litter. The number of spiders will increase when the layer of leaves litter increase. The deep leave litter provides more spaces for spiders to hide and avoid the extreme temperature. The weaving spiders such as the member of Araneidae make circle silk web in the air between the leaves and branches and in the front of broken stones (Foleix, 1996). The differences in the physical structure of leaf litter and its complexity can influence the species composition, spider abundance and diversity, it is generally increasing with increased litter depth in some studies (Uetz, 1979; Buddle and Rypstra, 2003).

The plantation area is the habitat that has the lowest diversity of diversity as the place is dominated by one plant only, namely clove. Furthermore, the sampling was conducted during clove harvesting period so that the habitat was disturbed by the human activities. The cleaning activities under clove tree disturb the presence of spiders. There are some environment disturbances that negatively affect the abundance and the diversity of spiders, including: the cultivation of the soil, the plan pruning and the use of synthetic pesticides (Samu et al., 1996; Reichert and Lockley, 1984; Kostanjšek et al., 2015). Generally, the increase of habitat disturbances will lead to the decrease of the species. Therefore, the change of the physical structure of the environment has a great influence on the preference of spiders' habitat, especially the species of spiders that make the web (Whitmore, 2002).

Acknowledgements. The author would like to thank the DIT. Litabmas Directorate General of Higher Education that has granted Competence Research Grants of the fiscal year 2016 to fund this research. 


\section{REFERENCES}

[1] American Museum of Natural History. (2016): The world spider catalog version 17.0. Currently valid spider genera and species (2016-02-02). [Cited 2016 Februay 2]. Available from http://www.wsc.nmbe.ch/statistics/\#.

[2] Barrion, A.T., Litsinger, J.A. (1995): Riceland spider of South and Southeast Asia International Rice Research Institute. Manila: CAB International.

[3] Bell, J.R., Wheater, C.P., Cullen, W.R. (2001): The implications of grassland and heathland management for the conservation of spider communities: a review. - J. of Zoo. 255: 377-387.

[4] Borror, B.J., Triplehorn , C.A., Johnson N.F. (1996): An Introduction to the Study of Insects . 6th edition. - Gajah Mada University Press: Yokyakarta, Indonesia:.

[5] Brunnet, B. (2000): Spider Watch: A guide to Australian Spiders. - Reed New Holland: Sydney.

[6] Buddle, C.M., Rypstra, A.L. (2003): Factors initiating emigration of two wolf spider species (Aranae: Lycosidae) in an agroecosystem. - Env. Ent. 32:88-95.

[7] Cardoso, P., Scharff , N., Gaspar, C., Henriques, S.S., Carvalho, R., Castro, P.H., Schmidt, J.B., Silva, I., Szüts, T., De Castro, A., Crespo, L.C. (2008): Rapid biodiversity assessment of spiders (Araneae) using semi-quantitative sampling: a case study in a Mediterranean forest. - Insect Con. and Diversity 1: 71-84 doi: 10.1111/j.17524598.2007.00008.x

[8] Chen, K.C., Tso, I.M. (2004): Spider diversity on Orchid Island, Taiwan: A Comparison between Habitats Receiving Different Degrees of Human Disturbance. - Zoo. Stud. 43(3): 598-611

[9] Chew, R.M. (1961): Ecology of spiders of desert community. . J. New York Ent. Soc (9):5-41.

[10] Enriquez, C.M.D., Nuñeza, O.M. (2014): Cave spiders in Mindanao, Philippines. ELBA Bioflux 6(1): 46-55.

[11] Floren, A., Muller, T., Deeleman-Reinhold, C., Linsenmair (2011): Effects of forest fragmentation on canopy spider communities In se-asian rain forests. - Ecotropica 17: 1526.

[12] Foelix, R.F. (1996): Biology of spider. 2 nd ed. - Oxford University Press: New York.

[13] Galle, R., Schweger, S. (2014): Habitat and landscape attributes influencing spider assemblages at lowland forest river valley (Hungary). - J. of Zoo. 10 (1): 36-41.

[14] Greenstone, M.H. (1984): Determinants of web spider species diversity: vegetation structural diversity vs. prey availability. - Oecologia 62: 299-304.

[15] Hawksworth, D.L., Kalin-Arroyo, M.T. (1995): Magnitude and distribution of biodiversity. - In: Heywood, V.H. (ed) Global Biodiversity Assessment. United Nations Environment Pro- gramme. London: Cambridge University Press.

[16] Kapoor, V. (2006): An assessment of spider sampling methods in tropical rainforest fragment of the anamalai hills, Western Ghats, India. - Zoo. Print J. 21 (12):2483-2488.

[17] Larrivee, M., Buddle, C.M. (2010): Scale dependence of tree trunk spider diversity patterns in vertical and horizontal space. - Ecoscience 17:400-410.

[18] Levi, H.W., Levi, L.R. (1990): Spider and Their Kin. - Golden Press: New York.

[19] Magurran, A.E. (1988): Ecological Diversity And Its Measurements. - London: Croom Helm Limited. London.

[20] Magguran, A.E. (2004): Measuring Biological Diversity. - Blackwell Publishing: Malden

[21] McDonald, B. (2007): Effects of vegetation structure on foliage dwelling spider assemblages in native and non-native Oklahoma grassland habitats. - Proc. Okla. Acad. Sci. 87: 85-88.

[22] Kainde, R.P. (2011): Tree Species biodiversity of the mount Sahendaruman protection forest in Sangihe Island Regency. - Eugenia 17: 1-9. 
[23] Kostanjšek, R., Kuralt, Ž., Sivec, N., Velkavrh, M. (2015). Comparison of spider diversity in two temperate forests by a rapid survey and its potential in nature conservation studies. - Appl. Ecol. and Env. Res. 13(3): 693-708. DOI: 10.15666/aeer/1303_693708

[24] Mineo, M.F., Claro, K.D. (2010): Diversity of tropical spiders-ground-dwelling spescies of Brazilian Savannas. - Tropical Biology Conservation Management XI.

[25] Morse, D.H. (1984): How crab spiders (Araneae: Thomisidae) hunt at flowers. - J of Arach.(12): 307-316.

[26] Ohsawa, M. (2005): Species richness and composition of Curculionidae (Coleoptera) in a conifer plantation, secondary forest, and old-growth forest in the central mountainous region of Japan. - Eco. Researc. 20: 632-645.

[27] Oyewole, O.A., Oyelade, O.J. (2014): Diversity and distribution of spiders in Southwestern Nigeria. - N Natural Resources 5:926-935. http://dx.doi.org/10.4236/nr.2014.515079

[28] Pollard, S.D., Beck, M.W., Dodson, G.N. (1995): Why do male scrab spiders drinks nectar? - Anim. Behav. 49: 1443-1448.

[29] Puja, K. (2014): Diversity of spiders fauna from Sarangpuri Lake, Arvi, Vidarbha Region. - Int. J. of Life Sci. 2(2): 165-167.

[30] Riechert, S.E., Lockleyal, T. (1984): Spiders as biological control agents. - Annu. Rev. of Entomol. (29):229-320.

[31] Samu, F., Sunderland,K.D., Topping, C.J., Fenlon, J.S. (1996): A spider population in flux: selestion and abandonment of artificial web-sites and the importance of intraspecific interactions in Lepthyphantes tenuis (Aranae: Linyphiidae) in wheat. - Oecologia 106: 228-239.

[32] Schuldt, A., Fahrenholz, N., Brauns, M., Migge-Kleian, S., Platner, C., Schaefer, M. (2008): Communities of ground-living spiders in deciduous forests: Does tree species diversity matter? - Biodiv. and Cons. 17: 1267-1287.

[33] Song, D.X., Zhang, J.X.,. Li, D. (2002): A checklist of spiders from Singapore (Arachnida: Araneae). - The Raffles Bull. of Zoo. 50(2): 359-388

[34] StatSoft (2001): Stastistica for windows, 6.0. Statsoft Inc. Tulsa: Oklohoma.

[35] Stenchly, K. (2010): Spider communities in Indonesian cacao agroforestry: diversity, web density and spatio-temporal turnover. Dissertation. Zur Erlangung des Doktorgrades der Mathematisch-Naturwissenschaftlichen Fakult der Georg-August-Universität zu Göttingen.

[36] Stenchly, K. (2011): Checklist of spiders from Indonesia and New Guinea (Arachnida: Araneae). This checklist is based on data of The World Spider Catalog, Version 11.5 by Norman I. Platnick . available at: http://research.amnh.org/iz/spiders/catalog/ INTRO1.html ) and includes all spiders that were decsribed for Indonesia and New Guinea.

[37] Suana, I.W. (2004): Bioekology of spiders in ricefield landscape at Cianjur. West Java. Dissertation. - School of Post Graduate Studies of Bogor Agricultural University. Bogor, Indonesia, 1-128.

[38] Uetz, G.W. (1979): The influence of variation in litter habitats on spider communities. Oecologia (40): 29-42. doi:10.1007/BF00388808

[39] Uniyal, V.P., Sivakumar, K., Quasin, S. (2011): Diversity of Spiders in Nanda Devi Biosphere Reserve. - Wildlife Institute of India, Dehradun. (DST Project Completion Report): 1-200.

[40] Vincent, V., Hadrien., L. (2013): Standardized sampling protocol for spider community assessment in the neotropical rainforest. - J.of Ento. and Zool. Studi. 1(2): 18-34.

[41] Whitmore, C., Slotow, R., Crouch, T.E., Dippenaar-Schoeman, A.S. (2002): Diversity of spiders (Araneae) in a Savanna Reserve, Northern Province, South Africa. - J. of Arach. (30): 344-356. http://dx.doi.org/10.1636/0161-8202(2002)030[0344:DOSAIA] 2.0.CO;2 


\section{APPENDIX}

Appendix 1. List of spider species collected from Sahendaruman Mountain, Sangihe Islands, North Sulawesi, Indonesia

\begin{tabular}{|c|c|c|c|c|c|}
\hline No. & $\begin{array}{l}\text { Family/ } \\
\text { Spescies }\end{array}$ & $\begin{array}{l}\text { No. } \\
\text { Indiv. }\end{array}$ & No. & $\begin{array}{l}\text { Family/ } \\
\text { Spescies }\end{array}$ & $\begin{array}{l}\text { No. } \\
\text { Indiv. }\end{array}$ \\
\hline & Araneidae & & & Oonopidae & \\
\hline 1 & Araneus sp. & 2 & 30 & Oonopoides sp. & 2 \\
\hline 2 & Argiope picta & 3 & 31 & Silhouettella loricatula & 5 \\
\hline 3 & Argiope sp. & 2 & 32 & Triaeris sp. & 2 \\
\hline 4 & Cyclosa sp.1 & 3 & & Oxyopidae & \\
\hline 5 & Cyclosa sp.2 & 2 & 33 & Oxyopes elegans & 2 \\
\hline 6 & Cyrtarachne sp. & 1 & 34 & Oxyopes quadrifasciatus & 3 \\
\hline 7 & Eriophora sp.1 & 10 & 35 & Oxyopes sp.1 & 9 \\
\hline 8 & Eriophora sp. 2 & 21 & 36 & Oxyopes sp. 2 & 2 \\
\hline 9 & Gasteracantha clavatrix & 25 & 37 & Oxyopes variabilis & 2 \\
\hline 10 & Gasteracantha sp. & 2 & & Pholcidae & \\
\hline 11 & Gibbaranea gibbosa & 1 & 38 & Pholcus sp. & 1 \\
\hline 12 & Gibbaranea sp.1 & 6 & & Salticidae & \\
\hline 13 & Gibbaranea sp.2 & 1 & 39 & Cosmophasis micarioides & 10 \\
\hline 14 & Hysosinga rubens & 1 & 40 & Cosmophasis sp. & 2 \\
\hline 15 & Lariniodes sp. & 1 & 41 & Cosmphasis baehrae & 1 \\
\hline \multirow[t]{2}{*}{16} & Phonognatha sp. & 22 & 42 & Euophrys sp.1 & 10 \\
\hline & Clubionidae & & 43 & Euophrys sp.2 & 2 \\
\hline 17 & Clubiona comta & 4 & 44 & Euryattus sp.1 & 19 \\
\hline 18 & Clubiona genevensis & 9 & 45 & Euryattus sp.2 & 1 \\
\hline 19 & Clubiona sp.1 & 4 & 46 & Hasarius sp. & 7 \\
\hline 20 & Clubiona sp.2 & 1 & 47 & Jotus sp. & 10 \\
\hline \multirow[t]{2}{*}{21} & Clubiona sp. 3 & 1 & 48 & ligonipes semitectus & 7 \\
\hline & Linyphiidae & & 49 & Myrmarachne intermichelis & 11 \\
\hline 22 & Ceratinella sp. & 1 & 50 & Myrmarachne isolata & 2 \\
\hline 23 & Erigonella sp. & 4 & 51 & Myrmarachne sp. & 8 \\
\hline \multirow[t]{2}{*}{24} & Linyphia sp. & 2 & 52 & Omoedus sp. & 4 \\
\hline & Lycosidae & & 53 & Opisthoncus parcedentatus & 24 \\
\hline 25 & Lycosa godeffroyi & 4 & 54 & Opisthoncus sp. & 4 \\
\hline 26 & Lycosa sp. & 1 & 55 & Phidippus sp. & 1 \\
\hline 27 & Pardosa sp. & 13 & 56 & Phintella sp. & 2 \\
\hline \multirow[t]{2}{*}{28} & Trochosa sp. & 6 & 57 & Plexippus sp. & 1 \\
\hline & Nephilidae & & 58 & Prostheclina sp. & 1 \\
\hline 29 & Nephila sp. & 1 & 59 & Pseudicius sp. & 1 \\
\hline
\end{tabular}




\begin{tabular}{|c|c|c|}
\hline No. & $\begin{array}{l}\text { Family/ } \\
\text { Spescies }\end{array}$ & $\begin{array}{l}\text { No. } \\
\text { Indiv. }\end{array}$ \\
\hline 60 & Pystira ephippigera & 90 \\
\hline 61 & Rhombonatus gracilis & 7 \\
\hline 62 & Salticus sp. & 30 \\
\hline 63 & Sandalodes sp. & 1 \\
\hline 64 & Sibianor sp. & 2 \\
\hline 65 & Simaetha sp. & 2 \\
\hline 66 & Telamonia dimidiata & 19 \\
\hline 67 & Telamonia sp. & 1 \\
\hline 68 & Telamonia vlijmi & 2 \\
\hline 69 & $\begin{array}{l}\text { Viciria } \mathrm{sp} . \\
\text { Scytodidae }\end{array}$ & 3 \\
\hline 70 & $\begin{array}{l}\text { Scytodes thoracica } \\
\text { Sparassidae }\end{array}$ & 54 \\
\hline 71 & $\begin{array}{l}\text { Heterophoda sp. } \\
\text { Tetragnathidae }\end{array}$ & 25 \\
\hline 72 & Leucauge decorata & 4 \\
\hline 73 & Tetragnatha extensa & 1 \\
\hline 74 & Tetragnatha montana & 1 \\
\hline 75 & Tetragnatha reimoseri & 1 \\
\hline 76 & $\begin{array}{l}\text { Tetragnatha striata } \\
\text { Theridiidae }\end{array}$ & 1 \\
\hline 77 & Anelosimus sp.1 & 16 \\
\hline 78 & Anelosimus sp.2 & 1 \\
\hline 79 & Anelosimus sp.3 & 1 \\
\hline 80 & Argyrodes flavescens & 1 \\
\hline 81 & Argyrodes rainbowi & 1 \\
\hline 82 & Argyrodes sp. & 3 \\
\hline 83 & Chrysso nigra & 1 \\
\hline 84 & Chrysso sp.1 & 1 \\
\hline 85 & Enoplognatha ovata & 2 \\
\hline 86 & Enoplognatha sp.1 & 27 \\
\hline 87 & Enoplognatha sp.2 & 1 \\
\hline
\end{tabular}

\begin{tabular}{|c|c|c|}
\hline No. & $\begin{array}{l}\text { Family/ } \\
\text { Spescies }\end{array}$ & $\begin{array}{l}\text { No. } \\
\text { Indiv. }\end{array}$ \\
\hline 88 & Enoplognatha sp.3 & 13 \\
\hline 89 & Euryopis elegans & 1 \\
\hline 90 & Euryopis sp.1 & 4 \\
\hline 91 & Steatoda sp. & 1 \\
\hline 92 & Theridion sp.1 & 1 \\
\hline 93 & $\begin{array}{l}\text { Theridion sp. } 2 \\
\text { Thomisidae }\end{array}$ & 1 \\
\hline 94 & Cozyptilla blackwalli & 1 \\
\hline 95 & Cymbacha saucia & 1 \\
\hline 96 & Diaea sp.1 & 6 \\
\hline 97 & Diaea sp.2 & 1 \\
\hline 98 & Diaea sp.3 & 2 \\
\hline 99 & Diaea sp.4 & 1 \\
\hline 100 & Ozyptila sp. & 1 \\
\hline 101 & Stephanopis sp.1 & 3 \\
\hline 102 & Stephanopis sp.2 & 2 \\
\hline 103 & Stephanopis sp.3 & 1 \\
\hline 104 & Stephanopis sp.4 & 1 \\
\hline 105 & Tharpyna diademata & 15 \\
\hline 106 & Thomisus onustus & 5 \\
\hline 107 & Thomisus spectabilis & 60 \\
\hline 108 & Tmarus marmoreus & 1 \\
\hline 109 & Tmarus sp.1 & 17 \\
\hline 110 & Tmarus sp. 2 & 1 \\
\hline 111 & Tmarus sp. 3 & 2 \\
\hline 112 & Xysticus acerbus & 5 \\
\hline 113 & Xysticus sp.1 & 3 \\
\hline 114 & Xysticus sp. 2 & 1 \\
\hline 115 & $\begin{array}{l}\text { Xysticus sp.3 } \\
\text { Zodariidae }\end{array}$ & 2 \\
\hline 116 & Storena formosa & 35 \\
\hline 117 & Storosa sp. & 15 \\
\hline \multicolumn{3}{|c|}{ Grand Total } \\
\hline
\end{tabular}

